\title{
Raw bovine meat fatty acids profile as an origin discriminator
}

\author{
L.G. Dias ${ }^{\text {a }}$, D.M. Correia ${ }^{\text {a }}$, J. Sá-Morais ${ }^{\text {a }}$,F. Sousa ${ }^{\text {a }}$, J.M. Pires ${ }^{\text {a }}$, A.M. Peres ${ }^{\text {a,b,* }}$ \\ ${ }^{a}$ CIMO - Mountain Research Centre, Escola Superior Agrária de Bragança, Instituto Politécnico de Bragança \\ ${ }^{\mathrm{b}}$ LSRE - Laboratory of Separation and Reaction Engineering, Escola Superior Agrária de Bragança, Instituto Politécnico de Bragança, \\ Quinta de Santa Apolónia, Apartado 1172, 5301-855 Bragança, Portugal
}

\begin{abstract}
Consumers are very concerned in "Protected Designation of Origin" (PDO) products, namely meat, since they associate these products to quality and healthy foods. Thus, it is necessary to implement analytical methodologies that could assure consumers about the products they purchase. Since this kind of meat is usually sold with no information concerning cattle sex, age and slaughter season, these characteristics were intentionally not taken into account. In this study, two Portugueses PDO bovine breeds (Mirandesa and Barrosã) and two production sub-systems (traditional and organic farming) were studied during a two-year period. Statistical analysis showed that production system and breed had a significant effect on the overall raw meat fatty acids (FA) content. Besides, the FA profiles could be used as an effective tool to differentiate the four groups studied allowing a $100 \%$ correct classification. The meat FA content was also correlated with the relative importance of the animal feeding stuff area.
\end{abstract}

Keywords: Bovine breed; Fatty acids; Linear discriminant analysis; Meat differentiation; Production systems

\section{Introduction}

It is well known that the preference of consumers for organic or traditional foods is increasing, since it is assumed that those products are healthier and their quality is above-average (Hermansen, 2003). For the common consumer a close relationship is made between "Protected Designation of Origin" (PDO) products and healthy food, particularly if they are able to associate to those PDO the breed and the production sub-system (organic and traditional productions). In fact, the consumer's decision to purchase a specific food, especially in developed countries, is greatly influenced by the perception of the food 'healthiness', which in the case of meat is largely related to its fat content and its fatty acid composition, namely the polyunsaturated fatty acids (PUFA), monounsaturated fatty acids (MUFA) and the saturated fatty acids (SFA) contents (Çelik et al., 2004; Eriksson \& Pickova, 2007; Fisher et al., 2000; Warren et al., 2008; Wood et al., 2003).
In this work, the fatty acids profile of two PDO breeds, from the north of Portugal, Mirandesa (M) and Barrosã's (B) breeds, according to two production sub-system, traditional $(\mathrm{T})$ and organic farming $(\mathrm{OF})$ were studied. Some studies concerning these two kinds of local autochthonous bovines found an influence of slaughter season, sex and animal age on the fatty acid composition (Brígido et al., 2004; Costa et al., 2006; da Silva, Lemos, Monteiro \& Portugal, 1998; Prates, Quaresma, Bessa, Fontes, \& Alfaia, 2006; Simões \& Mendes, 2003; Simões \& Mira, 2002; Simões, Mira, Lemos, \& Mendes, 2005). However, this kind of information is usually not given when meat is purchased. On the contrary, consumers are more concerned about certification of meat origin. It is known that Mirandesa-PDO and Barrosã-PDO veals have unique genetic characteristics being produced in well defined geographic regions with typical production systems (Cânon et al., 
2003; Sanchez et al., 2003), and thus specific fat compositions might be expected (Costa et al., 2006). This last information could be used in order to distinguish breeds and production sub-systems.

Therefore, the main objective of this work was to develop a methodology, based on the fatty acid profiles as well as in the SFA, MUFA, PUFA, PUFA:SFA and n6:n3 PUFA contents, in order to differentiate the meat production sub-system (traditional and organic farming) used and two autochthonous bovine cattle breeds (Mirandesa and Barrosã) studied using statistical analysis (parametric analysis of variance and linear discriminant analysis) even if some aspects were not taken into account, namely the animal sex, age and slaughter season. It was also intended to indirectly evaluate if the bovine meat FA content founded for each group studied could be related with the relative importance of the animal feeding stuff area of each farm.

\section{Materials and methods}

\subsection{Animals and production systems}

Bovine raw meat samples, from PDO Mirandesa and Barrosã's breeds of the north of Portugal, were obtained directly from four selected producers: two of them used a traditional production system (one for each breed) and the other two used an organic farming production system. In accordance with the legislation, traditional production system of these two PDO breeds is based on grazing and hay from meadows and other permanent grasslands including shrubs and forest, supplemented with the annual forages produced in the farms (e.g.: turnips, beetroots, regional maize fodder plant, rye forage and oat forage). The calves usually suck milk from their mothers and at 3 months of age they begin to be supplemented with farm products, especially with oat, rye and hay. In the traditional production, the calves are also supplemented with concentrates that the farmer purchases, in order to promote the finishing of the carcass. Organic farming, compared with the traditional way of producing, does not allow the use of any no certified commercial composed foods and forbids the use of chemical fertilizers for annual organic crops. The Portuguese regulatory board of organic farming follows the European legislation for this production system, Reg 1804/99 for animal production and Reg 2092/91 for organic farming in general, while the PDO(s) follow the European Reg 2081/92. In the two systems the animals are slaughtered at normal weaning age (7-9 months of age). The feeding stuffs land use in the four farms under study is resumed in Table 1.

In this study, samples from 33 different animals, collected during a two-year period, were analyzed: 6 animals ( 3 males and 3 females) from Mirandesa traditional cattle production (MT); 7 animals (6 males and 1 female) from Mirandesa organic cattle production (MOF); 8 animals ( 5 males and 3 females) from Barrosã traditional cattle pro-
Table 1

Feeding stuffs land used in the four farms for animal feed

\begin{tabular}{lcccc}
\hline Land use & \multicolumn{2}{l}{ Area (ha) } & & \\
\cline { 2 - 5 } & MT & MOF & BT & BOF \\
\hline Meadow & 9.4 & 16.2 & 8.7 & 22.6 \\
Cereal-fallow rotation & 30.3 & 21.1 & 0 & 0 \\
Double crop & 1.3 & 1.5 & 2.3 & 4.1 \\
Other permanent grasslands & 0 & 7.2 & 6.9 & 7.8 \\
Total & 41.0 & 46.0 & 17.9 & 34.5 \\
\hline
\end{tabular}

duction (BT) and 12 animals ( 2 males and 10 females) from Barrosã organic cattle production (BOF). Bovine meat samples were obtained from cattle with ages ranging from 6 to 13 months and $70-250 \mathrm{~kg}$ of carcass weight. The samples were taken from the Longissimus dorsi muscle of the 10th rib. One day after slaughter in commercial abattoir according to standard procedures, about $200 \mathrm{~g}$ of $L$. dorsi muscle were excised, vacuum packed and stored at $-80{ }^{\circ} \mathrm{C}$ until analysis.

\subsection{Reagents}

All reagents used were of analytical grade purity: methanol and diethyl ether were supplied by Lab-Scan; butylated hydroxytoluene (BHT) and undecanoic acid (C11:0) were from Sigma-Aldrich; sodium sulphate anhydrous $\left(\mathrm{Na}_{2} \mathrm{SO}_{4}\right)$ and chloroform $\left(\mathrm{CHCl}_{3}\right)$ from Merck; potassium chloride $(\mathrm{KCl})$ from Panreac; toluene $\left(\mathrm{C}_{7} \mathrm{H}_{8}\right)$ from Riedelde-Haën; sulphuric acid $\left(\mathrm{H}_{2} \mathrm{SO}_{4}\right)$ and heptadecanoic acid (C17:0) from Fluka. The fatty acids methyl ester reference standard mixture (C4-C24, FAME Mix 37) was from Supelco and purchased to Sigma-Aldrich. Deionised ultra-pure water was obtained from a Milli-Q50 equipment.

\subsection{Sample preparation}

The meat samples were minced in a meat grinder and lyophilized (Snijders Scientific lyophilisater equipment) during two days at $-89^{\circ} \mathrm{C}$ and stored in a desiccator until used, at room temperature. Before extraction, each meat sample was milled into a fine powder and homogenized. After that, approximately $1.5 \mathrm{~g}$ of the lyophilized mince was weighed and $1 \mathrm{ml}$ of internal standard (C11:0) with a concentration of $200 \mu \mathrm{g} / \mathrm{ml}$, prepared in chloroform:methanol 2:1 (vol/vol), and $50 \mu 1$ of $7.2 \%$ BHT was added. Fatty acids (FA) were extracted according to Folch, Lees, and Stanley (1957) method, using for the first and second extractions $30 \mathrm{ml}$ and $20 \mathrm{ml}$ of chloroform:methanol 2:1 (vol/vol), respectively. After adding $8 \mathrm{ml}$ of aqueous $\mathrm{KCl}$ solution $(0.37 \%)$ and $10 \mathrm{ml}$ of water:chloroform:methanol 47:3:48 ( $\mathrm{vol} / \mathrm{vol})$ to the pooled chloroform:methanol extract, the lipids in the chloroform phase were dried using a Büchi RE111 rotative evaporator, at $45^{\circ} \mathrm{C}$, under vacuum. After the evaporation, the FA were methylated with $5 \mathrm{ml}$ of methanol:sulphuric acid:toluene 2:1:1 ( $\mathrm{vol} / \mathrm{vol}$ ), 
overnight in a bath at $50{ }^{\circ} \mathrm{C}$ and $160 \mathrm{rpm}$ (Julabo Shake Temp SW22). Then $5 \mathrm{ml}$ of deionized water were added, to obtain phase separation. The FAME were recovered with $5 \mathrm{ml}$ of diethyl ether by shaking in a vortex (VM2 from CAT). This phase (upper) was passed through a hand made micro-column of sodium sulphate anhydrous, in order to eliminate the water. The sample was recovered in a vial with Teflon. Before injection the sample was filtrated with $0.2 \mu \mathrm{m}$ nylon filter from Millipore. For each sample the extraction procedure was repeated three times.

\subsection{Gas chromatography analysis}

GLC analysis of FAME was carried out in GC 1000 instrument from DANI equipped with a split/splitless injector, a flame ionisation detector (FID) and a DB Wax column $\left(30 \mathrm{~m} \times 0.32 \mathrm{~mm}\right.$ ID $\left.\times 0.5 \mathrm{~m} d_{\mathrm{f}}\right)$ from $\mathrm{J} \& \mathrm{~W}$. The oven temperature program was as follows: the initial temperature of the column was $50^{\circ} \mathrm{C}$, held for $2 \mathrm{~min}$, then a $10{ }^{\circ} \mathrm{C} / \mathrm{min}$ ramp was used until a $240{ }^{\circ} \mathrm{C}$ was obtained and held for $11 \mathrm{~min}$. The carrier gas (hydrogen) flow rate was $4.0 \mathrm{ml} / \mathrm{min}(0.61 \mathrm{bar})$, measured at $50^{\circ} \mathrm{C}$. Split injection $(1: 13)$ was carried out at $250^{\circ} \mathrm{C}$, being the detector at $260^{\circ} \mathrm{C}$. For each analysis $1 \mu \mathrm{l}$ of the sample was injected in GC equipment. For identification, the reference sample of FAME Mix Supelco 37 (C4-C24) was used. The results were recorded and processed using CSW 1.7 software (DataApex). The validation of the method for the determination and quantification of the fatty acids was accomplished by testing the precision (repeatability, reproducibility and intermediate precision) and the accuracy.

The internal standard (IS) method was used to calibrate the chromatographic system for the FA quantification. The undecanoic acid $(\mathrm{C} 11: 0)$ was chosen as the IS because it was not detected in the fat fractions of the beef raw meats analyzed. For quantification purposes the Internal Standard Method 2 of the DataApex 1.7 software was used. For this method, the IS concentration is kept constant in all analyses. Therefore, the concentration of each FA in the meat sample is obtained using the response factor for each FA, calculated from the calibration, multiplied by the concentration of the IS and by the response of the FA present in the sample divided by the response of the IS in the same injection. Each meat sample was analyzed at least three times.

The precision of the method was evaluated taking into account its repeatability, reproducibility and intermediate precision. The study was carried out with: (i) the reference sample of FAME Mix Supelco 37 (C4-C24); and, (ii) a meat sample of Barrosã's breed. The objective was to simultaneously study the precision of the injection and of the overall method (extraction and GC analysis).

The repeatability and reproducibility evaluation of the injection was made using the FAME Mix reference standard, by analyzing five times in the same day and three times in five consecutive days, respectively.
For repeatability and reproducibility of the overall method one raw meat sample of $5.84 \mathrm{~g}( \pm 0.01 \mathrm{~g})$, corresponding to $1.5 \mathrm{~g}$ of lyophilized meat of Barrosã's breed was chosen randomly and, after extraction, the FA content was analyzed five times in the same day and three times in five consecutive days, respectively. Concerning the intermediate precision, three extractions of the same raw meat sample were performed and each one was analyzed in triplicate in two consecutive days.

Recovery studies were carried out to determine the accuracy of the method, by determining the recovery percentages of pure heptadecanoic acid (C17:0) quantities added to raw meat samples. Two assays were made, by adding $20 \mu \mathrm{g}$ and $200 \mu \mathrm{g}$ of C17:0 to $1.5 \mathrm{~g}$ of lyophilized Barrosã and Mirandesa raw meat samples, respectively.

\subsection{Statistical analysis}

All data were subjected to multivariate analysis of variance (MANOVA) using general linear model (GLM) procedures with two fixed factors (production system and breed). For MANOVA analysis the Wilks' Lambda and Pillai Trace tests were used for significant effects evaluation. Linear discriminant analysis (LDA) was also performed, in order to obtain classification rules for differentiation between production systems and cattle breed. This is the most common used supervised pattern recognition method and the best studied one. It provides a classification model, characterized by a linear dependence of the classification scores with respect to the descriptors (groups previously defined), which maximize the ratio between-class variance and minimize the ratio of withinclass variance. LDA assumes an a priori knowledge of the group membership of each sample in a training set. In LDA, groups are supposed to follow a multivariate normal distribution and not be linearly dependent (Berrueta, Alonso-Salces, \& Héberger, 2007; López, García, \& Garrido, 2008; Rencher, 1995). The normality and homogeneity of variance were studied using the Shapiro-Wilk test and the Levene test, respectively. Pearson Chi-square test of association was also performed in order to evaluate the correlation between the LDA's scores and the percentage of the cultivation area used in each farm for feeding stuffs production. All the statistical analysis was performed using the JMP and SPSS software.

\section{Results and discussion}

Typical chromatograms depicting fatty acid separation of a standard solution and of a raw meat of organic farming Barrosã's sample are shown in Fig. 1. The percentage variation coefficient $(\mathrm{CV} \%)$ obtained for the response factor (Rf), for each FA of the FAME Mix reference standard, are shown in Table 2. As can be seen from the Table 2, the CV values for repeatability and reproducibility assays, for the different FAs of the FAME Mix reference standard, are between $1 \%$ and $8 \%$, and $1 \%$ and $11 \%$, 

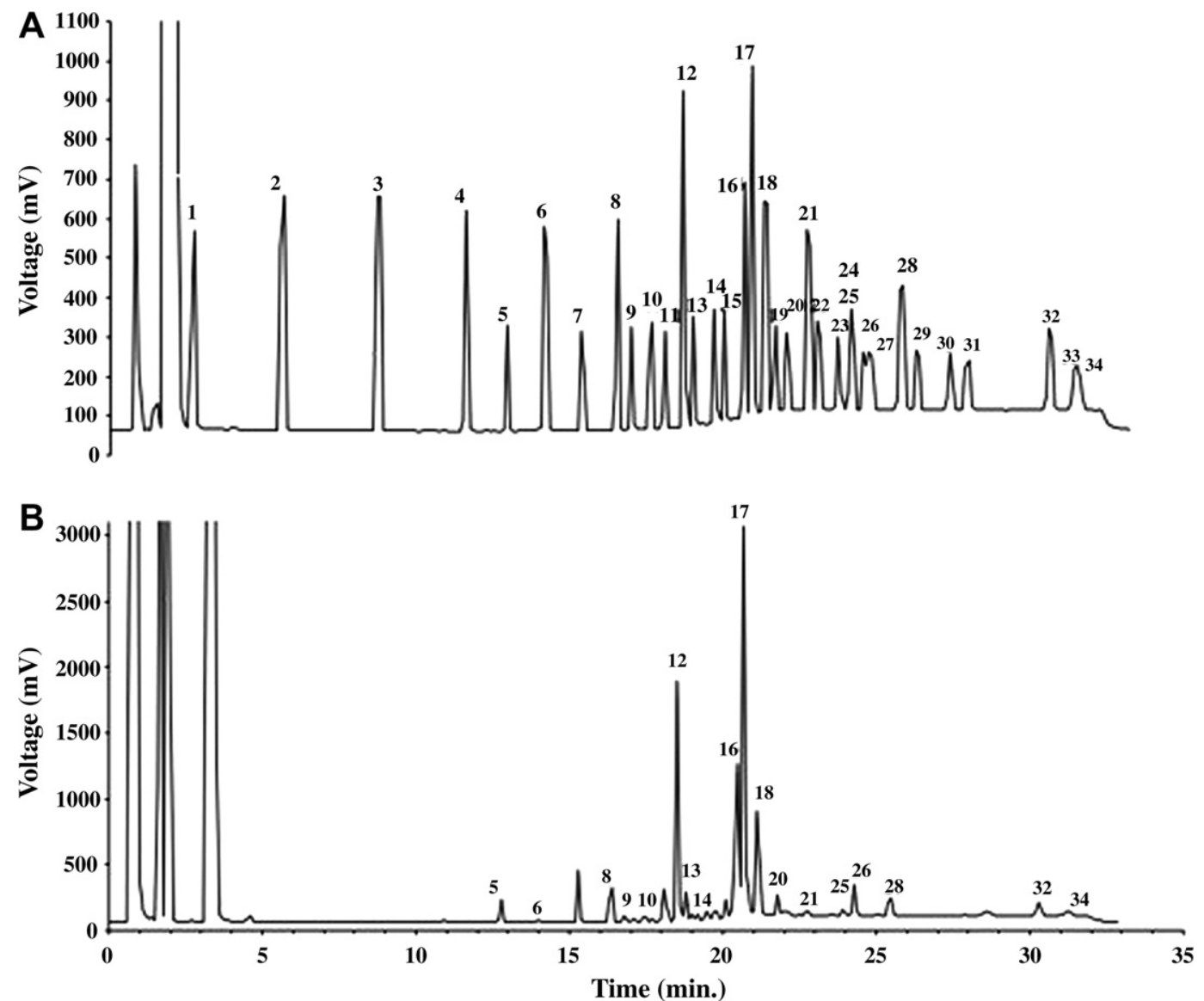

Fig. 1. Chromatograms for: (A) FAME Mix reference standard and (B) FAME present in raw meat of organic farming Barrosã's sample. (1) C4:0; (2) C6:0; (3) C8:0; (4) C10:0; (5) C11:0; (6) C12:0; (7) C13:0; (8) C14:0; (9) C14:1; (10) C15:0; (11) C15:1; (12) C16:0; (13) C16:1; (14) C17:0; (15) C17:1; (16) $\mathrm{C} 18: 0 ;(17) \mathrm{C} 18: 1 \mathrm{n} 9 \mathrm{c}+\mathrm{C} 18: 1 \mathrm{n} 9 \mathrm{t} ;(18) \mathrm{C} 18: 2 \mathrm{n} 6 \mathrm{c}+\mathrm{C} 18: 2 \mathrm{n} 6 \mathrm{t} ;$ (19) C18:3n6; (20) C18:3n3; (21) C20:0; (22) C20:1; (23) C20:2; (24) C20:4n6; (25) C21:0; (26) C20:3n3 + C20:3n6; (27) C20:5n3; (28) C22:0; (29) C22:1n9; (30) C22:2; (31) C23:0; (32) C24:0; (33) C22:6n3; (34) C24:1.

Table 2

Repeatability and reproducibility for the response factor of each FA present in the FAME Mix reference standard

\begin{tabular}{|c|c|c|c|c|c|}
\hline Fatty acids & Repeatability $(\mathrm{CV} \%)$ & Reproducibility (CV\%) & Fatty acids & Repeatability $(\mathrm{CV} \%)$ & Reproducibility $(\mathrm{CV} \%)$ \\
\hline$\overline{\mathrm{C} 4: 0}$ & 3 & 7 & $\mathrm{C} 18: 2 \mathrm{n} 6 \mathrm{c}+\mathrm{C} 18: 2 \mathrm{n} 6 \mathrm{t}$ & 2 & 7 \\
\hline C6:0 & 4 & 5 & C18:3n6 & 2 & 6 \\
\hline $\mathrm{C} 8: 0$ & 3 & 3 & $\mathrm{C} 18: 3 \mathrm{n} 3$ & 2 & 7 \\
\hline $\mathrm{C} 10: 0$ & 1 & 1 & $\mathrm{C} 20: 0$ & 4 & 10 \\
\hline C11:0 & $(*)$ & $(*)$ & $\mathrm{C} 20: 1$ & 4 & 10 \\
\hline $\mathrm{C} 12: 0$ & 2 & 2 & $\mathrm{C} 20: 2$ & 5 & 9 \\
\hline C13:0 & 2 & 4 & $\mathrm{C} 20: 4 \mathrm{n} 6$ & 4 & 7 \\
\hline $\mathrm{C} 14: 0$ & 5 & 6 & $\mathrm{C} 21: 0$ & 1 & 3 \\
\hline C14:1 & 4 & 6 & $C 20: 3 n 3+C 20: 3 n 6$ & 5 & 9 \\
\hline C15:0 & 3 & 9 & $\mathrm{C} 20: 5 \mathrm{n} 3$ & 5 & 10 \\
\hline C15:1 & 3 & 8 & C22:0 & 8 & 8 \\
\hline $\mathrm{C} 16: 0$ & 4 & 2 & $\mathrm{C} 22: \ln 9$ & 4 & 8 \\
\hline C16:1 & 5 & 2 & $\mathrm{C} 22: 2$ & 4 & 8 \\
\hline $\mathrm{C} 17: 0$ & 3 & 5 & $\mathrm{C} 23: 0$ & 2 & 8 \\
\hline $\mathrm{C} 17: 1$ & 3 & 4 & $\mathrm{C} 24: 0$ & 4 & 10 \\
\hline C18:0 & 2 & 7 & $\mathrm{C} 22: 6 \mathrm{n} 3$ & 4 & 4 \\
\hline $\mathrm{C} 18: \ln 9 \mathrm{c}+\mathrm{C} 18: \ln 9 \mathrm{t}$ & 1 & 6 & C24:1 & 4 & 11 \\
\hline
\end{tabular}

(*) Internal Standard.

respectively; being half of them less than $4 \%$ and $7 \%$, respectively, which are of a similar magnitude than those reported by Aldai, Osoro, Barrón, and Nájera (2006) for repeatability assays $(\leqslant 6 \%)$. 
Table 3

Repeatability, reproducibility and intermediate precision results regarding fatty acids concentration in raw beef from organic farming Barrosã's PDO meat

\begin{tabular}{|c|c|c|c|c|}
\hline \multirow[t]{2}{*}{ Fatty acids } & \multirow{2}{*}{$\begin{array}{l}\text { mg FA/ } \\
100 \mathrm{~g} \text { of } \\
\text { raw } \\
\text { meat }\end{array}$} & \multicolumn{3}{|l|}{$\mathrm{CV}(\%)$} \\
\hline & & Repeatability & Reproducibility & $\begin{array}{l}\text { Intermediate } \\
\text { precision }\end{array}$ \\
\hline $\mathrm{C} 12: 0$ & 3.6 & 2 & 3 & 2 \\
\hline C14:0 & 81.0 & 8 & 12 & 9 \\
\hline C14:1 & 9.4 & 8 & 12 & 10 \\
\hline C15:0 & 10.2 & 9 & 16 & 14 \\
\hline $\mathrm{C} 16: 0$ & 392.1 & 8 & 19 & 18 \\
\hline $\mathrm{C} 16: 1$ & 47.0 & 9 & 18 & 17 \\
\hline $\mathrm{C} 17: 0$ & 15.4 & 7 & 21 & 20 \\
\hline C18:0 & 215.2 & 6 & 21 & 22 \\
\hline $\begin{array}{l}\mathrm{C} 18 \mathrm{~s} \ln 9 \mathrm{c} \\
\quad+\mathrm{C} 18: \ln 9 \mathrm{t}\end{array}$ & 507.2 & 7 & 14 & 24 \\
\hline $\begin{array}{l}\mathrm{C} 18 \mathrm{i} 2 \mathrm{n} 6 \mathrm{c} \\
\quad+\mathrm{C} 18: 2 \mathrm{n} 6 \mathrm{t}\end{array}$ & 64.3 & 8 & 20 & 22 \\
\hline $\mathrm{C} 18: 3 \mathrm{n} 3$ & 14.6 & 7 & 22 & 22 \\
\hline C20:0 & 1.6 & 10 & 19 & 23 \\
\hline C21:0 & 7.2 & 8 & 20 & 26 \\
\hline $\begin{array}{l}\mathrm{C} 20: 3 \mathrm{n} 3 \\
\quad+\mathrm{C} 20: 3 \mathrm{n} 6\end{array}$ & 42.9 & 7 & 19 & 25 \\
\hline $\mathrm{C} 22: 0$ & 11.7 & 9 & 19 & 25 \\
\hline $\mathrm{C} 24: 0$ & 11.2 & 14 & 19 & 21 \\
\hline C24:1 & 3.8 & 13 & 22 & 21 \\
\hline
\end{tabular}

The mean values of the response factor vary between 0.7 and 2.2 , being in general around $1.0 \pm 0.2$. The retention times of each FA of the FAME Mix reference standard present a CV less than $0.3 \%$ for the repeatability and reproducibility studies.
The mean total FA content $(\mathrm{mg} / 100 \mathrm{~g}$ of raw meat) of beef meat for a organic farming Barrosã's PDO sample, calculated from the intermediate precision assays, as well as the CV values obtained for repeatability, reproducibility and intermediate precision are given in Table 3. It should be remarked that in the real samples only 17 fatty acids were able to be quantified. The CV values obtained in this study, varying from $2 \%$ to $26 \%$, are similar to those reported in the literature for reproducibility assays in beef meat (Aldai, Osoro et al., 2006). These authors found that the CV (\%) for five sub-samples of the same meat sample injected in one day, varied from $8 \%$ to $25 \%$. Some of the CV (\%) obtained in this work, for raw meat samples, are slightly higher values $(\geqslant 20 \%)$. However, it should be kept in mind the nature of the extraction process and the complexity of the chromatographic analysis (Aldai, Osoro et al., 2006). Therefore, it can be stated that this method is able to quantify FA of meat samples with satisfactory precision. Moreover, the FA concentration $(\mathrm{mg} / 100 \mathrm{~g})$ obtained for Barrosã-PDO raw beef meat are similar to those reported by Aldai, Osoro et al. (2006) for bulls of Asturiana breed and by Serrano et al. (2005) for restructured beef steak.

Regarding the two recovery assays made (addition of $20 \mu \mathrm{g}$ and $200 \mu \mathrm{g}$ of C17:0 to $1.5 \mathrm{~g}$ of lyophilized Barrosã and Mirandesa raw meat samples, respectively) it was found that recoveries were of $84 \%$ and $81 \%$, respectively. The results are satisfactory and in accordance with those obtained by Aldai, Osoro et al. (2006) for beef meat (81$143 \%)$.

Table 4

FA mean composition and standard deviation (w/w\%) for Mirandesa's and Barrosã's breeds according to the production system used: organic farming (OFprod) or traditional (TRADprod)

\begin{tabular}{|c|c|c|c|c|}
\hline \multirow[t]{2}{*}{ Fatty acids } & \multicolumn{2}{|c|}{ Mirandesa's breed (w/w\%) } & \multicolumn{2}{|c|}{ Barrosã’s breed (w/w\%) } \\
\hline & OFprod (mean $\pm \mathrm{s})$ & TRADprod $($ mean $\pm \mathrm{s})$ & OFprod (mean $\pm \mathrm{s})$ & TRADprod (mean $\pm \mathrm{s})$ \\
\hline $\mathrm{C} 12: 0$ & $0.16 \pm 0.05$ & $0.19 \pm 0.05$ & $0.14 \pm 0.04$ & $0.16 \pm 0.02$ \\
\hline $\mathrm{C} 14: 0$ & $4.76 \pm 0.83$ & $5.30 \pm 0.77$ & $3.79 \pm 0.75$ & $4.65 \pm 0.52$ \\
\hline $\mathrm{C} 15: 0$ & $0.64 \pm 0.08$ & $0.55 \pm 0.05$ & $0.61 \pm 0.15$ & $0.74 \pm 0.08$ \\
\hline $\mathrm{C} 16: 0$ & $29.04 \pm 2.97$ & $26.95 \pm 3.92$ & $28.07 \pm 3.72$ & $29.05 \pm 1.74$ \\
\hline $\mathrm{C} 16: 1$ & $4.63 \pm 0.60$ & $3.80 \pm 0.51$ & $3.47 \pm 0.90$ & $3.16 \pm 0.12$ \\
\hline $\mathrm{C} 18: \ln 9 \mathrm{c}+\mathrm{C} 18: \ln 9 \mathrm{t}$ & $27.12 \pm 2.81$ & $27.46 \pm 3.42$ & $26.00 \pm 1.94$ & $30.76 \pm 4.80$ \\
\hline $\mathrm{C} 18: 2 \mathrm{n} 6 \mathrm{c}+\mathrm{C} 18: 2 \mathrm{n} 6 \mathrm{t}$ & $6.82 \pm 1.46$ & $6.72 \pm 0.62$ & $7.97 \pm 1.96$ & $6.53 \pm 1.35$ \\
\hline $\mathrm{C} 18: 3 \mathrm{n} 3$ & $1.26 \pm 0.24$ & $1.24 \pm 0.18$ & $1.06 \pm 0.25$ & $1.62 \pm 0.17$ \\
\hline $\mathrm{C} 20: 0$ & $0.09 \pm 0.01$ & $0.11 \pm 0.02$ & $0.09 \pm 0.02$ & $0.11 \pm 0.00$ \\
\hline $\mathrm{C} 21: 0$ & $0.53 \pm 0.14$ & $0.57 \pm 0.09$ & $0.71 \pm 0.18$ & $0.46 \pm 0.05$ \\
\hline $\mathrm{C} 20: 3 \mathrm{n} 3+\mathrm{C} 20: 3 \mathrm{n} 6$ & $4.71 \pm 1.20$ & $5.48 \pm 0.88$ & $5.11 \pm 1.26$ & $3.41 \pm 0.49$ \\
\hline MUFA & $32.56 \pm 2.82$ & $32.73 \pm 3.58$ & $30.09 \pm 2.34$ & $34.50 \pm 5.07$ \\
\hline PUFA & $11.79 \pm 1.73$ & $13.19 \pm 1.26$ & $13.26 \pm 1.96$ & $11.80 \pm 1.64$ \\
\hline PUFA:SFA & $0.24 \pm 0.05$ & $0.25 \pm 0.04$ & $0.26 \pm 0.04$ & $0.22 \pm 0.02$ \\
\hline n6:n3PUFA & $5.18 \pm 0.96$ & $5.47 \pm 0.77$ & $8.39 \pm 1.33$ & $3.90 \pm 0.55$ \\
\hline
\end{tabular}


The method developed was used for separation and quantification of the FA present in both breeds (Mirandesa and Barrosã) and production systems (organic farming and traditional). The mean FA composition (w/w $\%$ ) obtained based on three replicates of one sample of each 7, 6, 18 and 6 animal carcasses of MOF, MT, BOF and BT, respectively, are shown in Table 4. It has been reported (Costa et al., 2006) that FA composition of intramuscular lipids fractions in Barrosã-PDO veal was significantly affected by slaughter season and sex. Nevertheless, the degree of such influence was dependent of the muscle considered, being more important for Biceps femoris and Supraspinauts muscle than for $L$. dorsi muscle. Since the last one was the muscle studied in this work, the possible effects of sex and slaughter season were not taken into account. This decision was also due to the dimension of the samples for each production sub-system and animal breed and also since it was intended to investigate if it was possible to use de FA profile for breed and production sub-system differentiation, independently of the animal sex, age and slaughter season as already discussed.

In this work, the major FA were represented by $\mathrm{C} 16: 0$ $(26-29 \%), \quad \mathrm{C} 18: 0 \quad(15-16 \%), \quad \mathrm{C} 18: 1 \mathrm{n} 9 \mathrm{c}+\mathrm{C} 18: 1 \mathrm{n} 9 \mathrm{t} \quad(26-$ $30 \%)$ and $\mathrm{C} 18: 2 \mathrm{n} 6 \mathrm{c}+\mathrm{C} 18: 2 \mathrm{n} 6 \mathrm{t}(6.5-8 \%)$, which accounted an overall minimum percentage of $70 \%$. It should be kept in mind that, depending of the breed, diet composition, animal sex, slaughter season and muscle analyzed, different FA profiles are expected. The above-mentioned results are in agreement with those reported by Nuernberg et al. (2005), for Longissimus muscle from German Holstein and German Simmental bulls; Aldai, Osoro et al. (2006) and Aldai, Murray et al. (2006), for Longissimus thoracis muscle samples from bulls of Asturiana breed; Costa et al. (2006), for Biceps femoris, Supraspinatus and L. dorsi muscle from veals of Barrosã breed; and Marino et al. (2006), for L. dorsi, Semimembranosus and Semitendinosus muscle from Podolian young bulls. Moreover, the good agreement obtained with the results reported by Costa et al. (2006) is of major importance, since it refers to the same breed and the same muscle studied in this work.

The normality of the data was tested globally using the Shapiro-Wilk's test due to the sample dimension. It was found that, in general the experimental data as well as their unstandardized residuals present a normal distribution $(P \geqslant 0.064$ and $P \geqslant 0.10$, respectively), except in nine cases: C12:0, C14:1, C18:1n9c, C20:0; C20:3n3; C24:0, C24:1; PUFA:SFA and n6:n3 PUFA ratios. Moreover, the homogeneity of variance for the four groups considered was also verified by means of the Levene's test $(P \geqslant 0.10)$.

For the data that achieve normality distribution as well as variance homogeneity a MANOVA two-way was performed. The MANOVA's results allowed to conclude that the production system and the animal breed had a significant effect in whole variables analyzed $(P=0.013$ and $P=0.003$ obtained by the Wilks' Lambda and Pillai Trace tests, for production system and animal breed, respectively). Moreover, no significant interaction effect was observed for breed and production system $(P=0.928$ for Wilks' Lambda and Pillai Trace tests). However the possible effect of each one of the above-mentioned factors in the meat fatty acid profile was not studied since factors such as animal sex, age and slaughter season were disregarded in the experimental design, since it was not the objective of the present work. Linear Discriminant Analysis was applied in order to differentiate the production sub-systems and animal breeds. The objective was to apply a procedure of supervised pattern recognition in order to better achieve the above-mentioned differentiation, by obtaining corresponding discriminant functions as linear combinations of the chemical descriptors. This technique was used for the classification of vinegars based on their polyalcohols content (Antonelli, Zeppa, Gerbi, \& Carnacini, 1997), the varietal differentiation of red wines in the Spanish Valencian region (Aleixandre, Lizama, Alvarez, \& García, 2002), the determination of geographic origin of potatoes using their content in mineral and trace elements (Di Giacomo, Del Signore, \& Giaccio, 2007) and to discriminate between table olives according to their mineral nutrient composition (López et al., 2008). Although this method requires the normality distribution of the data, it can deal with deviations from normality, having good robustness. Therefore, all the variables (FA profile MUFA, PUFA, SFA, PUFA:SFA and n6:n3 ratios) were taken into account. However, the model obtained used all the variables (shown in Table 4) except the following ones: C24:0, C24:1, SFA, MUFA and PUFA, since these last variables failed the tolerance test. For group differentiation, the first two discriminant functions were selected, and took into account $68.3 \%$ and $25.2 \%$ of the total variance, respectively. The data obtained are shown in Fig. 2.

The results show that it is possible to discriminate between the four groups considered in this study, even if important effects, such as animal sex, age and slaughter season were not considered. Thus this approach could be used to assure consumers about the origin of the meat products they purchased. In fact, a correct classification of $100 \%$ was observed for all the four groups showing high sensibility and specificity. Fig. 2 shows that, considering discriminant factor 1 , the BOF group was observed on the far right side, whereas the MOF, BT and MT groups were observed in the left side, being the last one on the far negative region. In addition the MOF group had positive score according to discriminant factor 2, whereas BT group has negative scores and MT and BOF groups are located close to the origin. It can be observed that data from BOF group has a better separation from the other three groups and with less spread distribution. Therefore, the FA profile obtained together with the PUFA:SFA and n6:n3 ratio can be used as an effective tool to discriminate the breed and production sub-system used. Nevertheless, it is important to recognize the need of a larger number of meat samples in order to support a better understanding of the role of breed and production system on the fatty acids profile. 




Fig. 2. Discriminant analysis obtained by discriminant functions 1 and 2 for the fatty acids content for all the meat samples $(\bigcirc \mathrm{MOF}$; MT; $\bullet$ BOF and * BT).

Finally it was studied the existence of a possible correlation between the discriminant scores and the feeding stuffs land use in the four farms under study (Table 1), in order to evaluate if the feeding stuffs land use could have contributed to the separation between animal breeds and productions systems. In fact it has been reported in the literature that the FA content of bovine meat is affected by the dietary animal intake (Eriksson \& Pickova, 2007; Warren et al., 2008).

A Pearson correlation test was performed in order to establish the dependence between the scores obtained for discriminant function 1 and the percentages of the feeding stuff production area used. The results obtained show a high positive correlation $(0.917)$ with meadow area, a high negative correlation $(-0.762)$ with cereal-fallow rotation area and a positive medium correlation (0.660) with double crop area, being the correlations obtained significant at a $5 \%$ significance level $(P<0.001$ with the Bonferroni probabilities test). The analysis concerning the scores obtained with the discriminant function 2 shows that only the correlation with double crop area is significant $(P=0.004$ for the Bonferroni probabilities test) and negative $(-0.575)$. As expected, these results show an evidence that the meat FA content observed for each animal breed and production sub-system could be related with the relative importance of the animal feeding stuff area. Additional studies are being carried out in order to obtain the FA profile of the diets (meadows, other permanent grasslands, maize, small-grain cereals and others) with the purpose of comparing and establishing the dietary effects on the bovine meat FA content.

\section{Conclusions}

The results obtained for the data collected during two years clearly show that the raw meat fatty acids profile was able to discriminate between the four groups considered in this study: Barrosã breed with traditional production, Barrosã breed with organic farming production, Mirandesa breed with traditional production and Mirandesa breed with organic farming production. This result shows that, even if the cattle sex, age and slaughter were not taken into account, the fatty acid profile can be used to differentiate the origin of the two PDO meat products studied and thus can be employed as a meat origin discriminator, reinforcing the consumers's confidence when this kind of product is bought. The results also show that the meat fatty acids content observed for each animal breed and production sub-system could be related with the relative importance of the animal feeding stuff area, mainly to the meadow percentages production area. However, further studies are needed in order to reinforce this conclusion.

\section{Acknowledgments}

This work was supported under project AGRO no. 227, Programa AGRO, Medida 8.1. Special thanks are due to Associação dos Criadores de Bovinos de Raça Mirandesa (Portugal) and Associação dos Criadores de Bovinos de Raça Barrosã (Portugal).

\section{References}

Aldai, N., Osoro, K., Barrón, L. J. R., \& Nájera, A. I. (2006). Gas-liquid chromatographic method for analysing complex mixtures of fatty acids including conjugated linoleic acids (cis9trans11 and trans10cis12 isomers) and long-chain ( $n-3$ or $n-6)$ polyunsaturated fatty acids. Application to the intramuscular fat of beef meat. Journal of Chromatography A, 1100, 133-139.

Aldai, N., Murray, B. E., Oliván, M., Martínez, A., Troy, D. J., Osoro, K., et al. (2006). The influence of breed and mh-genotype on carcass 
conformation, meat physico-chemical characteristics, and the fatty acid profile of muscle from yearling bulls. Meat Science, 72, 486-495.

Aleixandre, J. L., Lizama, V., Alvarez, I., \& Garcia, M. J. (2002). Varietal differentiation of red wines in Valencian region (Spain). Journal of Agricultural and Food Chemistry, 50, 751-755.

Antonelli, A., Zeppa, G., Gerbi, V., \& Carnacini, A. (1997). Polyalcohols in vinegar as an origin discriminator. Food Chemistry, 60, 403-407.

Berrueta, L. A., Alonso-Salces, R. M., \& Héberger, K. (2007). Supervised pattern recognition in food analysis. Journal of Chromatography A, $1158,196-214$.

Brígido, C., da Fonseca, I. P., Parreira, R., Fazendeiro, I., do Rosário, V. E., \& Centeno-Lima, S. (2004). Molecular and phylogenetic characterization of Theileria spp. parasites in autochtonous bovines (Mirandesa breed) in Portugal. Veterinary Parasitology, 123, 17-23.

Cânon, J., Alexandrino, P., Bessa, I., Carleos, C., Carretero, Y., Dunner, S., et al. (2003). Genetic diversity measures of local European beef cattle breeds for conservation purposes. Genetics Selection Evolution, $33,311-332$.

Çelik, M., Türeli, C., Çelik, M., Yanar, Y., Erdem, Ü., \& Küçükgülmez, A. (2004). Fatty acid composition of the blue crab (Callinectes sapidus Rathbun, 1896) in the north eastern Mediterranean. Food Chemistry, 88, 271-273.

Costa, P., Roseiro, L. C., Partidário, A., Alves, V., Bessa, R. J. B., Calkins, C. R., et al. (2006). Influence of slaughter season and sex in fatty acid composition, cholesterol and $\alpha$-tocopherol contents on different muscles of Barrosã-PDO veal. Meat Science, $72,130-139$.

Da Silva, M. F., Lemos, J. P. C., Monteiro, L. S., \& Portugal, A. V. (1998). Studies on growth and form: Multivariate analysis of distribution of muscle and fat in Portuguese cattle breeds. Livestock Production Science, 55, 261-271.

Di Giacomo, F., Del Signore, A., \& Giaccio, M. (2007). Determining the geographic origin of potatoes using mineral and trace element content. Journal of Agricultural and Food Chemistry, 55, 860-866.

Eriksson, S. F., \& Pickova, J. (2007). Fatty acids and tocopherol levels in M. Longissimus dorsi of beef cattle in Sweden - A comparison between seasonal diets. Meat Science, 76, 746-754.

Fisher, A. V., Enser, M., Richardson, R. I., Wood, J. D., Nute, G. R., Kurt, E., et al. (2000). Fatty acid composition and eating quality of lamb types derived from four diverse breed $\times$ production systems. Meat Science, 55, 141-147.

Folch, J., Lees, M., \& Stanley, G. H. S. (1957). A simple method for the isolation and purification of total lipids from animal tissues. Journal of Biological Chemistry, 726, 497-509.
Hermansen, J. E. (2003). Organic livestock production systems and appropriate development in relation to public expectations. Livestock Production Science, 80, 3-15.

López, A., García, P., \& Garrido, A. (2008). Multivariate characterization of table olives according to their mineral nutrient composition. Food Chemistry, 106, 369-378.

Marino, R., Albenzio, M., Girolami, A., Muscio, A., Sevi, A., \& Bragheri, A. (2006). Effect of forage to concentrate ratio on growth performance, and on carcass and meat quality of Podolian young bulls. Meat Science, 72, 415-424.

Nuernberg, K., Dannenberger, D., Nuernberg, G., Ender, K., Voigt, J., Scollan, N. D., et al. (2005). Effect of grass-based and a concentrate feeding system on meat quality characteristics and fatty acid composition of longissimus muscle in different cattle breeds. Livestock Production Science, 94, 137-147.

Prates, J. A. M., Quaresma, M. A. G., Bessa, R. J. B., Fontes, C. M. G. A., \& Alfaia, C. M. P. M. (2006). Simultaneous HPLC quantification of total cholesterol, tocopherols and $\beta$-carotene in Barrosã-PDO veal. Food Chemistry, 94, 469-477.

Rencher, A. C. (1995). Methods of multivariate analysis. New York, USA: John Wiley.

Sanchez, A., Beja-Pereira, A., Cânon, J., Alexandrino, P., Bessa, I., Carretero, Y., et al. (2003). Genetic characterization of southwestern European bovine breeds: A historical and biogeographical reassessment with a set of 16 microsatellites. Journal of Heredity, 94, 243-250.

Serrano, A., Cofrades, S., Ruiz-Capillas, C., Olmedilla-Alonso, B., Herrero-Barbudo, C., \& Jiménez-Colmenero, F. (2005). Nutritional profile of restructured beef steak with added walnuts. Meat Science, 70, 647-654.

Simões, J. A., \& Mendes, I. A. (2003). Distribution of tissues in carcass at the same proportion of total carcass fat in Portuguese cattle breeds. Animal Research, 52, 287-298.

Simões, J. A., \& Mira, J. F. F. (2002). Age, empty body weight and carcass composition at the same proportion of total carcass fat in Portuguese cattle breeds. Livestock Production Science, 74, 159-164.

Simões, J. A., Mira, J. F. F., Lemos, J. P. C., \& Mendes, I. A. (2005). Dressing percentage and its relationship with some components of the fifth quarter in Portuguese cattle breeds. Livestock Production Science, 96, 157-163.

Warren, H. E., Scollan, N. D., Enser, M., Hughes, S. I., Richardson, R. I., \& Wood, J. D. (2008). Effects of breed and a concentrate or grass silage diet on beef quality in cattle of 3 ages. I. Animal performance, carcass quality and muscle fatty acid composition. Meat Science, 78, 256-269.

Wood, J. D., Richardson, R. I., Nute, G. R., Fisher, A. V., Campo, M. M., Kasapidou, E., et al. (2003). Effects of fatty acids on meat quality: A review. Meat Science, 66, 21-32. 